\title{
Functional Tests External File Path
}

National Cancer Institute

\section{Source}

National Cancer Institute. Functional Tests External File Path. NCI Thesaurus. Code C162134.

The literal identifier of a functional test external file name. 